\title{
腎細胞癌の免疫組織化学的研究
}

第 2 編＼cjkstart腎癌細胞の細胞膜糖鎖ならびに近位尿細管上皮抗原に関する研究

\begin{tabular}{|c|c|c|c|}
\hline $\begin{array}{c}\text { 筑波大学附属病院泌尿器科 } \\
\text { (主任: 小磯謙吉教授) }\end{array}$ & 飯 & 泉 & 達 \\
\hline $\begin{array}{l}\text { 帝京大学医学部泌层器科 } \\
\text { (主任: 和久正良教授) }\end{array}$ & 矢 & 崎 & \\
\hline 筑波大学臨床医学系泌层器科 & 加 & 納 & 勝 \\
\hline 磯請吉教授) & 小 & 磯 & \\
\hline 波大学臨床 & 小 & 山 & \\
\hline （主任：東條静夫教授） & 東 & 條 & 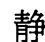 \\
\hline
\end{tabular}

\section{IMMUNOHISTOCHEMICAL STUDY OF RENAL CELL CARCINOMA}

II. Studies on the Glycocompounds and Renal Tubular Antigen of Renal Cell Carcinoma

Tatsuo lizumi

Department of Urology, Tsukuba University Hospital

(Director: Prof. K. Koiso)

Tsunetada Yazaki

Department of Urology, School of Medicine, Teikyo University

(Director: Prof. M. Waku)

Shohiri Kanoh and Kenkichi Koiso

Department of Urology, Institute of Clinical Medicine, The University of Tsukuba

(Director: Prof. K. Koiso)

Akio Koyama and Shizuo Tojo

Department of Internal Medicine, Institute of Clinical Medicine, The University of Tsukuba

(Director: Prof. S. Tojo)

A fluorescence study was performed on specimens from 20 primary and 2 metastatic sites and tumors themselves of TSU-R1, our new cell line derived from renal cell carcinoma, grown in nude mice using 3 lectins, soybean agglutinin (SBA), peanut agglutinin (PNA), and wheat germ agglutinin (WGA), and antibodies to renal tubular antigen (RTA).

Anti-RTA reacted with carcinoma cells in all specimens of primary tumors, while SBA reacted in 9 (45\%), PNA in $3(15 \%)$ and WGA in 11 (55\%). In carcinoma cells from metastatic sites, only SBA did not react with them. Although we observed the presence of RTA in the tumor of TSU-R1 transplanted to a nude mouse at the 10th passage, RTA could not be found in the tumor transplanted at thr 50th passage. WGA reacted with the carcinoma cells in both passages of the tumors of TSU-R1, but SBA and PNA did not bind to either of them.

This fluorescence study seems to be a simple and useful method to investigate the characteristics of renal cell carcinoma. Since changes of glycocompounds may correlated to malignant potential of the carcinoma cells, further study with lectins will be necessary.

要旨: 我々は, 20例の腎細胞癌組織, 腎細胞癌転移組織, およびヌードマウス移植腎細胞癌由来組織 （TSU-R1）において， 3 種類のレクチン（soybean agglutinin ; SBA. peanut agglutinin; PNA. wheat germ agglutinin; WGA) に対するモノクローナル抗体および抗近位尿細管上皮抗原抗体（抗PTA 抗 
体)を用い，蛍光抗体法拉よび蛍光染色を施行した。原発腫瘍組織に括いては，抗 RTA 抗体は全例で腫 瘍細胞と反応したが，SBA は 9 例 (45\%)，PNA は 3 例 (15\%), WGA は11例 (55\%) とのみ反応した。 転移組織では, SBA のみが腫湯細胞と反応を示さなかった. ヌードマウス移植組織においては, 抗 RTA 抗体は継代数 10 代の時点で作製した組織の腫瘍細胞とは反応したが，継代数50代と組織では反応を示さ なかった. WGA は継代数 10 代，50代の移植組織の両者に执いて腫瘍細胞と反応し，SBA，PNA は両者 ともに反応を示さなかった.

我々が今回用いた蛍光抗体法および蛍光染色は, 腎細胞癌個々の性質および特微を概略的に把握する ら劣に打いて簡単でかつ有効な方法と考兄られた。特に腫瘍細胞における glyco-compounds の変化はそ の腫瘍の臨床的な悪性度を推測させる指標となる可能性もあり,レクチンを用いた蛍光染色は, 今後更 に検討する必要があると考えられた。

\section{緒 言}

腎細胞癌は泌尿器性悪性腫瘍の中でも手術療法以外 の治療法には全く反応しない悪性腫瘍である1). 放射 線療法, 化学療法, 免疫 (補助) 療法などが無効であ る2) 4) ことは，この悪性腫瘍細胞の外で起こる現象が 細胞内部へ伝達されないことも原因の一つと推定され る.すなわち，この細胞膜表面での情報伝達に関する 細胞機能の障害が問題となる。このような細胞膜の機 能としては細胞膜の外側に存在し，様々な情報に対応 出来る構造物が先づ上げられ，一般には細胞膜の糖鎖 を含む脂質, 蛋白質が当核物質と考えられている.従っ て腎癌細胞に㧍ける細胞膜上のこれらの变化を追求す ることはひとり腎細胞癌の膜変化を検討するに止ら ず，疾患の臨床経過，予後を推定する上で極めて重要 である5)6)

一方, 腎細胞癌の発生病理が論じられ, 従来まで副 腎迷入説が唱えられてきたが，その形態学的(電顕的) 観察より近位尿細管起源であると考兄られている。 たその免疫学的反応性に関しても近位尿細管起源であ ると想定されている。従って腎細胞癌の heterogeneity を追求する目的で近位尿細管上皮抗原の検 討は臨床的にも極めて重要である7).

本研究はこの立場より腎細胞癌の細胞膜糖鎖をこれ と反応する 3 種類のレクチンを用い蛍光抗体法, 蛍光 染色法により検討した。また同様に近位尿細管上皮抗 原の検索も行い, 若干の知見をえたので報告する。

\section{研究対象および方法}

\section{1. 腎癌細胞組織および正常部腎組織}

1982年 12 月より 1985年 3 月までに筑波大学附属病院 泌尿器科に入院し, 腎細胞癌と診断され, 腎全摘除術 をらけた 20 症例よりえられた腎細胞癌組織である。そ の組織学的所見を表 1 亿示す。その分類基準は「腎癌 取り扱い規約」に準じた ${ }^{8)}$ 。腎細胞癌転移病巣は症例
表 1 Histological findings of primary renal cell carcinoma

\begin{tabular}{c|c|c|c|c}
\hline case & organization & cell type & grade & stage \\
\hline $1^{*}$ & alv. & $\mathrm{C}$ & $\mathrm{G} 1$ & $\mathrm{~T}_{2} \mathrm{~N}_{0} \mathrm{M}_{0}$ \\
2 & alv. & $\mathrm{C}$ & $\mathrm{G} 1$ & $\mathrm{~T}_{2} \mathrm{~N}_{0} \mathrm{M}_{0}$ \\
3 & alv. & $\mathrm{C}>\mathrm{D}$ & $\mathrm{G} 1$ & $\mathrm{~T}_{3} \mathrm{~N}_{0} \mathrm{M}_{0}$ \\
4 & papil. & $\mathrm{D}$ & $\mathrm{G} 1$ & $\mathrm{~T}_{3} \mathrm{~N}_{0} \mathrm{M}_{0}$ \\
5 & alv. +papil. & $\mathrm{D}$ & $\mathrm{G} 1$ & $\mathrm{~T}_{2} \mathrm{~N}_{0} \mathrm{M}_{0}$ \\
6 & alv. & $\mathrm{C}$ & $\mathrm{G} 1$ & $\mathrm{~T}_{2} \mathrm{~N}_{0} \mathrm{M}_{0}$ \\
7 & alv. & $\mathrm{D}>\mathrm{C}$ & $\mathrm{G} 1>\mathrm{G} 2$ & $\mathrm{~T}_{2} \mathrm{~N}_{0} \mathrm{M}_{0}$ \\
$8^{*}$ & alv. & $\mathrm{C}$ & $\mathrm{G} 1$ & $\mathrm{~T}_{2} \mathrm{~N}_{0} \mathrm{M}_{0}$ \\
9 & alv. & $\mathrm{C}>\mathrm{D}$ & $\mathrm{G} 1$ & $\mathrm{~T}_{2} \mathrm{~N}_{0} \mathrm{M}_{0}$ \\
10 & alv. & $\mathrm{C}$ & $\mathrm{G} 1$ & $\mathrm{~T}_{3} \mathrm{~N}_{0} \mathrm{M}_{0}$ \\
11 & alv. & $\mathrm{D}$ & $\mathrm{G} 1>\mathrm{G} 2$ & $\mathrm{~T}_{3} \mathrm{~N}_{2} \mathrm{M}_{0}$ \\
12 & alv. & $\mathrm{C}$ & $\mathrm{G} 1$ & $\mathrm{~T}_{2} \mathrm{~N}_{\mathrm{X}} \mathrm{M}_{1}$ \\
13 & alv. & $\mathrm{C}>\mathrm{D}$ & $\mathrm{G} 1$ & $\mathrm{~T}_{2} \mathrm{~N}_{0} \mathrm{M}_{0}$ \\
14 & alv. & $\mathrm{C}$ & $\mathrm{G} 1$ & $\mathrm{~T}_{2} \mathrm{~N}_{\mathrm{X}} \mathrm{M}_{1}$ \\
$15^{*}$ & alv. + papil. & $\mathrm{D}>\mathrm{C}$ & $\mathrm{G} 2>\mathrm{G} 1$ & $\mathrm{~T}_{2} \mathrm{~N}_{0} \mathrm{M}_{0}$ \\
$16^{*}$ & alv. & $\mathrm{C}$ & $\mathrm{G} 1$ & $\mathrm{~T}_{2} \mathrm{~N}_{0} \mathrm{M}_{0}$ \\
17 & alv. & $\mathrm{C}$ & $\mathrm{G} 1=\mathrm{G} 2$ & $\mathrm{~T}_{2} \mathrm{~N}_{\mathrm{X}} \mathrm{M}_{1}$ \\
18 & papil. & $\mathrm{D}>\mathrm{C}$ & $\mathrm{G} 1$ & $\mathrm{~T}_{3} \mathrm{~N}_{1} \mathrm{M}_{0}$ \\
19 & alv. & $\mathrm{C}$ & $\mathrm{G} 1$ & $\mathrm{~T}_{3} \mathrm{~N}_{0} \mathrm{M}_{0}$ \\
20 & alv. & $\mathrm{C}$ & $\mathrm{G} 1=\mathrm{G} 2$ & $\mathrm{~T}_{3} \mathrm{~N}_{\mathrm{X}} \mathrm{M}_{1}$ \\
\hline
\end{tabular}

alv. =alveolar type, papil. = papillary type

$\mathrm{C}=$ celear, $\mathrm{D}=$ dark

*indicate case with postoperative metastases

No. 20よりえられたもので, 肺並びに骨転移巣であ る. 対照とした正常腎組織は摘除腎のなかで腫瘍が比 較的小さく, 病巣より離れた部位より得た。尚, その 一部の検索より組織学的にも正常組織と確認してい る.

2. ヌードマウス移植腎細胞癌由来組織

1）腎細胞癌由来細胞株 TSU-R1の樹立

症例 No. 8の腎摘出術後可及的速やかにかつ無菌的 に腫瘍組織約 $1 \mathrm{~g}$ を採取して実験に供した。採取した腎 細胞癌組織をクリーンベンチ内において $0.01 \mathrm{M}$ リン 
酸緩衝液( $\mathrm{pH} 7.4$ )（以後 PBS と略す)，および0.02\% ethylendiamine tetraacetic acid (EDTA), pH 7.4k て十分に洗浄した後, 隇菌プラスチックシャーレに移 し，これに $0.25 \%$ トリプシン液 $3 \mathrm{ml}$ を加え組織を約 30 分間メスで細切した。これに増殖培地 $7 \mathrm{ml}$ を添加し, 1 分間静置後, 上清を遠沈管に移し, 300rpm で 1 分間遠 沈した。この上清を 3 ないし 4 個の培養フラスコに分 注し, 増殖培地を加兄て培養した。約 2 力月後, 癌細 胞の増殖を認めた。その後, 継代によって現在までに すでに60代を経過した。この腎細胞癌由来の培養細胞 株を TSU-R1と呼んでいる。継代数 50 代における染色 体分析では低四倍体で，染色体数は75から85の range をもっていた。また mode number は80であった。 リプシン・ギムザ分染色による核型分析の結果, 染色 体数 85 の細胞は i (1q), i (1p), 3q- i (7p), 11 $\mathrm{p}^{+}, 16^{+}$の 構造異常の染色体に加党, 16 個の marker chromosomeを有していた。同継代数での増殖倍加時 間は48時間であった。

2) TSU-R1ヌードマウス移植組織

腎細胞癌由来細胞株 TSU-R1の生細胞数 $1 \times 10^{6}$ 個分 をヌードマウス（BAL B/C nu" $/ \mathrm{nu}$ ) の背部皮下に注 入し，その移植状態を観察したところ注入後 1 から 2 カ月して直径 $2 \mathrm{~cm}$ 以上に腫瘍が増殖した. 以後ヌード マウスで継代し，本実験では継代数 10 代および50代の 時点での組織を研究対象とした。10代の時点での移植 腫瘍は50代に比べ明るい胞体を有する細胞が多く, 由 来組織の clear cell type により近い像を呈して扣り, 50代の腫瘍はかなり未分化な印象を受けた。

\section{3. 組織の処理}

各組織は採取後ただちに $1 \mathrm{~cm}$ 角前後に細切し,アセ トン・ドライアイス中にてへキサン固定した。 固定凍 結された組織をクライオスタットにて厚さ $2 \mu$ に薄切 し，封緘した後 $-20^{\circ} \mathrm{C}$ に保存した。

4.レクチンおよびその他の抗体 レクチンは E.Y. Laboratories 社 (San Mateo, U. S.A.) の FITC ラベル Soybean agglutinin (以後 SBA と略す), peanut agglutinin (以後 PNA と略す). wheat germ agglutinin (以後 WGA と略す) を使用 した.

5. FITC ラベル抗 RTA 抗体

RTA の抽出は成清等の方法に準じた ${ }^{9)}$.すなわち, 病理組織学上異常を認めない血液型 $\mathrm{O}$ 型剖検腎より皮 質のみを採取し，生理食塩水で洗浄した後，100，115, 170番の金属メッシュを順次通過させた。この皮質成分
をプロナーゼで消化後, Sephadex G-200にてゲル濾 過し，280nmに拈ける吸光度を測定してfraction curveを作成した，次に，家鬼を最初のピーク（Vo） を用いて兔疫し，抗血清を得た。これを人血清蛋白お よび人 liver powderにて十分吸収した後，1/3飽和硫 安塩折, DEAEセルロースを用いたカラムクロマトグ ラフィーにて抗 RTA 抗体の IgG 分画を得た。この分 画を透析法にて fluorescein isothiocyanate (以後 FITC と略す）をラベルしたが，Fluorescein/Protein 比は2.7であった。

6. 蛍光抗体法打よび监光染色

FITC ラベルレクチン执よびFITC ラベル抗 RTA 抗体による直接蛍光抗体法による蛍光染色は，先つ， 非特異反応を減じる目的にて $1 \%$ の割合でウシ血清ア ルブミンおよび0.1\%の割合でTween-80を含んだ $0.01 \mathrm{MPBS}, \mathrm{pH} 7.2$ 亿前述の方法で作製した薄切切片 を浸し，水和させた。次に湿箱に拈いて切片をレクチ ンまたは抗 RTA と反応させた後, 前述の PBS にて十 分洗浄した。切片に glycerin buffer を滴下し，カバー グラスをかけて蛍光䫓微鏡下で観察した。

7. neuraminidase 処理

SBA, PNA, WGA の 3 種のレクチンに関しては, 通 常の未処理の切片に対する蛍光染色に加えて, neuraminidase にて処理した切片に対しても営光染色を 行った. neuraminidase 処理は, neuraminidase (type V, SIGMA Chemical Co., St. Louis, U.S.A.) 0.02 $\mathrm{U} / \mathrm{ml}$ となる様に $0.01 \mathrm{M}$ 塩化カルシウムを含んだ 0.05 $\mathrm{M}$ トリス緩衝食塩水, $\mathrm{pH} 5.5$ に溶解し，切片と室温に て 1 時間反応させた。

\section{8. 結果の判定}

蛍光抗体法扣よび営光染色の結果は, 陰性 (一), 判 定困難 $( \pm)$, 弱陽性 $(1+)$, 中陽性 $(2+)$, 強陽性 $(3+)$ の 5 段階に分類した。また，蛍光の特異性は抗 RTA 抗体に対してはRTA，レクチンに対してはそれ ぞれに対する inhibiting sugar (SBA $=\mathrm{N}$-acetylgalactosamine, $\mathrm{PNA}=$ galactose, $\mathrm{WGA}=\mathrm{N}$-acetylglucosamine, SIGMA Chemical Co, St. Louis, U.S.A.) を予め反応させることにより蛍光が消失することを確 認している。また，これらの成績の統計学的判定は $\chi^{2}$ 検定によった。

\section{正常部腎組織}

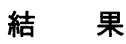

SBA は, 特徵的な顆粒状の蛍光が系球体, 近位扔よ び遠位尿細管の上皮細胞辺縁，基底膜，間質組織に認 
図 1 Binding of lectins to normal kidney tissues. Peculiar granular staining pattern of SBA is seen.

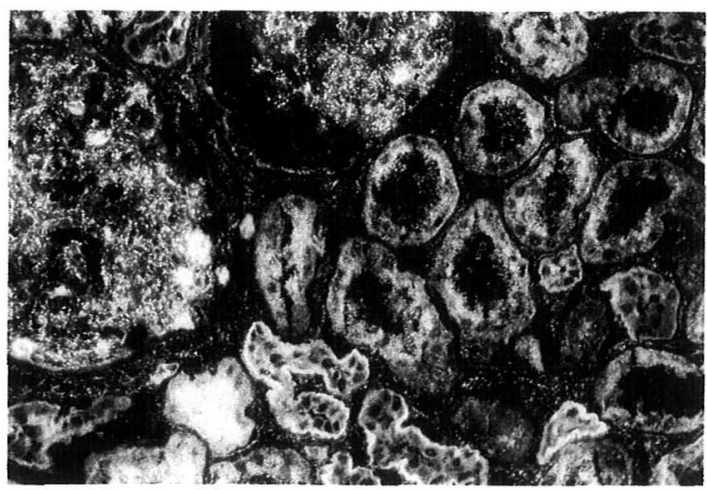

図 2 Binding of lectins to normal kidney tissues. PNA reacts predominantly with distal tubules but also faintly with Bowman's capsule.

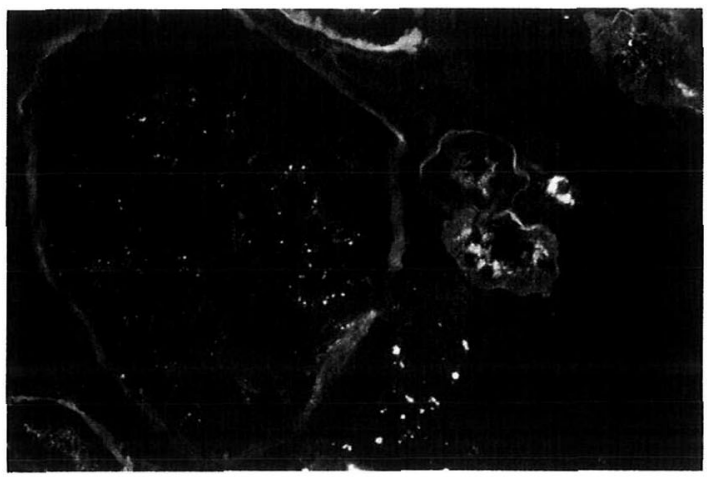

められた（図 1)，PNA は遠位尿細管の上皮細胞辺縁 拉よび基底膜と中等度に反応し, 糸球体ボウマン囊と も弱いながら反応を示した（図 2).WGA b SBA と ほぼ同様の部位に反応したが，蛍光は近位尿細管上皮 細胞においてやや弱く, 糸球体および遠位尿細管基底 膜では他と比べ強い蛍光が認められた（図 3). 一方, neuraminidase 処理切片に打けるレクチンの反応性 は, SBA では未処理および処理切片の間に葟とんど差 は認められなかったが, PNAでは処理切片に扎いて 糸球体, 近位尿細管基底膜に蛍光が認められるよらに なった。これと対照的に, WGA では処理切片において 糸球体の蛍光があきらかに減弱した。しかし, 他の部 位には変化は認められなかった（表 2 ）。

抗 RTA 抗体は近位尿細管上皮細胞と強く反応した が, 糸球体, 遠位尿細管, 間質組織とは反応しなかっ た (図 4 ).
図 3 Binding of lectins to normal kidney tissues. WGA reacts predominantly with glomerular capillary walls but also with proximal and distal tubules.

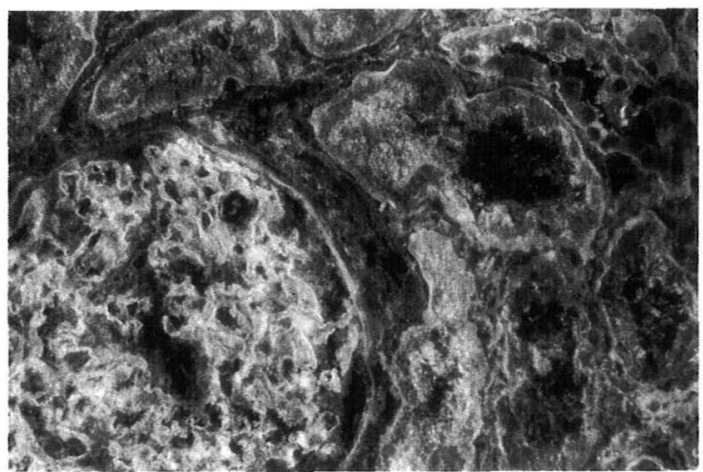

表 2 正常腎におけるレクチン反応性

\begin{tabular}{|c|c|c|c|c|}
\hline レクチン & $\begin{array}{l}\text { ノイラミダーゼ } \\
\text { 処理 }\end{array}$ & 糸球体 & 近位尿細管 & 遠位尿細管 \\
\hline \multirow{2}{*}{ SBA } & $(-)$ & + & + & + \\
\hline & $(+)$ & + & + & + \\
\hline \multirow{2}{*}{ PNA } & $(-)$ & \pm & - & + \\
\hline & $(+)$ & $\oplus$ & $\oplus$ & + \\
\hline \multirow{2}{*}{ WGA } & $(-)$ & + & + & + \\
\hline & $(+)$ & \pm & + & + \\
\hline
\end{tabular}

図 4 Distribution of renal tubular antigens in normal kidney tissue. Specific fluorescence is seen in proximal tubules.

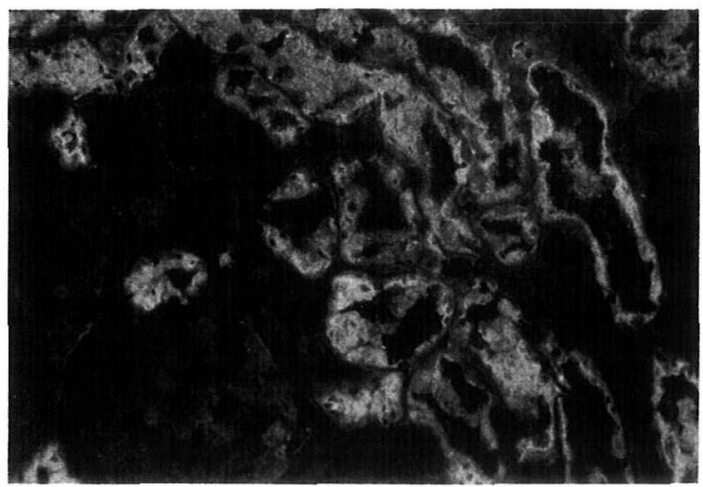

腎細胞癌組織

1. 原発腫瘍組織

a）腎癌細胞と間質細胞

腎細胞癌組織に拈けるレクチン反応性を検討すると 表 3 の如くである。腎癌細胞ではSBAレセプター, WGA レセプターはほぽその半数に, PNAレセプター 
表 3 腎癌細胞におけるレクチン反応（陽性率）

\begin{tabular}{c|r|r}
\hline レクチン & 腎癌細胞 & \multicolumn{1}{|c}{ 間質細胞 } \\
\hline SBA & $9 / 20(45 \%)$ & $20 / 20(100 \%)$ \\
PNA & $3 / 20(15 \%)$ & $4 / 20(20 \%)$ \\
WGA & $11 / 20(55 \%)$ & $20 / 20(100 \%)$ \\
\hline
\end{tabular}

図 5 Binding of lectins to primary renal cell carcinoma. SBA binding sites are observed at stromal tissue but not at carcinoma cells.

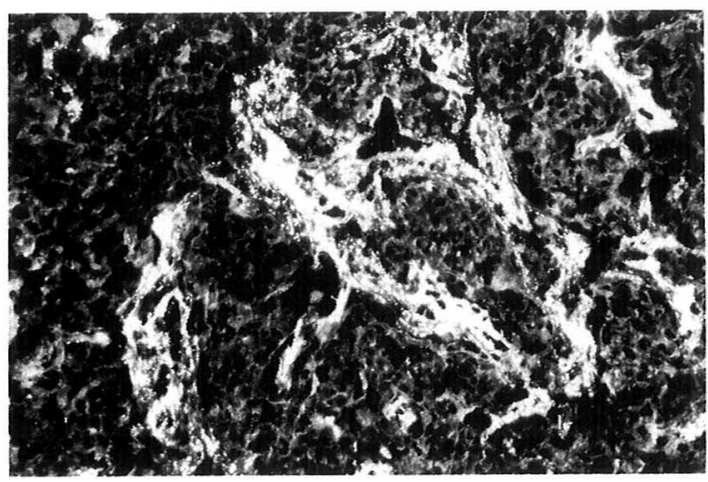

圀 6 Binding of lectins to primary renal cell carcinoma. Binding of PNA to carcinoma cells is seen in a small area.

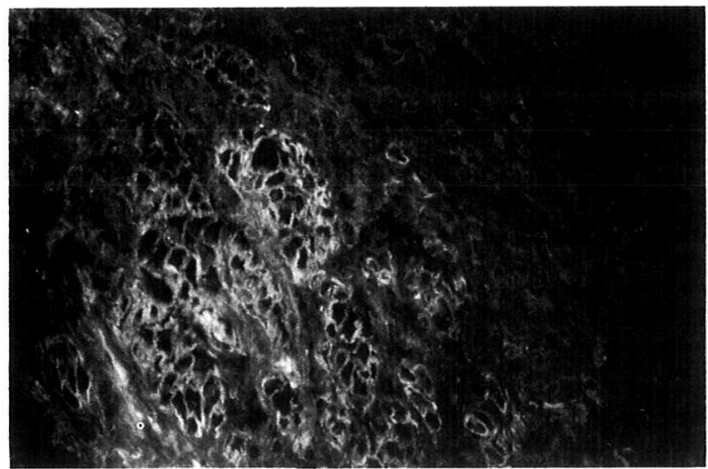

は15\%に陽性であった。一方, 腎細胞癌間質細胞では, SBA, WGA 全例に，PNA は20\%に陽性であった（図 $5,6,7$ )。

一方，腎尿細管抗原 (aRTA)はすべての症例で腎癌 細胞に陽性に出たが, 間質細胞には認められなかった。

b）腎細胞癌の細胞型

腎細胞癌の細胞型を明細胞型, 暗細胞型, およびそ の混合型に分けて検討した。 その結果を表 4 に示す。 SBA では, 明細胞型で $(+)$ 以上 5 例，（土） 1 例，(-) 5 例であった。暗細胞では $(+) 1$ 例，(ー) 2 例であっ
図 7 Binding of lectins to primary renal cell carcinoma. WGA binding sites are observed at both carcinoma cells and stromal tissue.

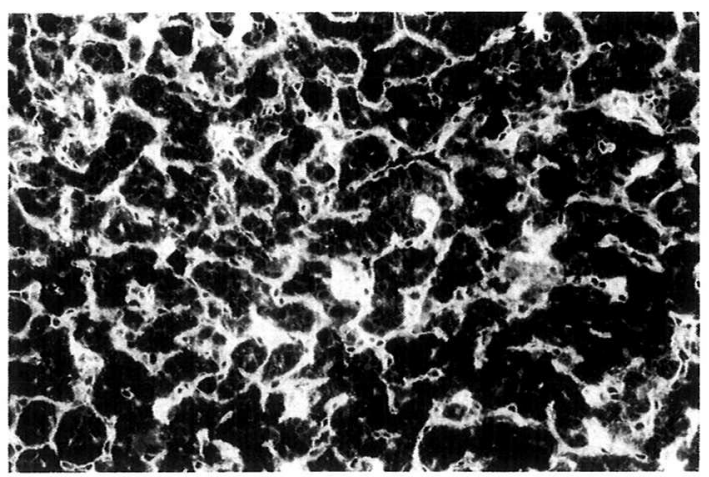

表 4 腎癌細胞におけるレクチン反応性と細胞型

\begin{tabular}{cc|c|c|c}
\hline \multirow{2}{*}{ レクチン } & \multicolumn{3}{|c}{ 細 胞 型 } \\
\cline { 3 - 5 } & & 明細胞型 & 暗細胞型 & 混 合 型 \\
\hline \multirow{3}{*}{ SBA* $^{*}$} & 5 & 1 & 3 \\
& \pm & 1 & 0 & 1 \\
& - & 5 & 2 & 2 \\
PNA $^{* *}$ & + & 3 & 0 & 0 \\
& \pm & 0 & 0 & 0 \\
& - & 8 & 3 & 6 \\
WGA $^{* * *}$ & + & 6 & 1 & 4 \\
& \pm & 4 & 1 & 2 \\
& - & 1 & 1 & 0 \\
\hline
\end{tabular}

${ }^{*},{ }^{* *},{ }^{* * *}:$ not significant (N.S.)

た。混合型では（+） 3 例，（土） 1 例，（一） 2 例で あった。PNAでは明細胞型11例中 3 例が陽性で他は 陰性であった。暗細胞型, 混合型ともに $(+),( \pm)$ の症例はなかった。 WGA は全体に(一)の症例が少な い傾向が伺えた。aRTAは一定の傾向が認められな かった。

c）腎細胞癌の分化度

腎細胞癌の分化度を $\mathrm{G} 1$ 抢よび $\mathrm{G} 2(\mathrm{G} 1+\mathrm{G} 2)$ とに分 けて検討した。

SBA では G1で陽性率が高かったが, G2 5 例では陽 性を示した症例はなかった。

PNA では，G1，G2とも陽性を示す症例より陰性を 示す症例の頻度が高かった。

WGA では, PNA と反対の傾向で, G1, G2 とも陽性 を示す症例が多かった（表 5 ）.

aRTA は一定の傾向を示さなかった。

d）腎細胞癌の T分類 
表 5 腎癌細胞におけるレクチン反応性と分化度

\begin{tabular}{lc|r|c}
\hline \multirow{2}{*}{ レクチン } & \multicolumn{2}{|c}{ 分 化 度 } \\
\cline { 3 - 4 } & & $\mathrm{G} 1$ & $\mathrm{G} 2(\mathrm{G} 1+\mathrm{G} 2)$ \\
\hline \multirow{3}{*}{$\mathrm{SBA}^{*}$} & + & 9 & 0 \\
& \pm & 1 & 1 \\
& - & 5 & 4 \\
PNA** $^{*}$ & + & 3 & 0 \\
& \pm & 0 & 0 \\
WGA $^{* * *}$ & - & 12 & 5 \\
& + & 9 & 2 \\
& \pm & 5 & 3 \\
\hline
\end{tabular}

* : significant, $\chi^{2}=12.89$, $\mathrm{p}$ less than 0.01

$* *, * * *$ not significant.

表 6 腎癌細胞におけるレクチン区応性と T分類

\begin{tabular}{ll|r|r}
\hline \multirow{2}{*}{ レクチン } & \multicolumn{2}{|c}{$\mathrm{T}$ 分 類 } \\
\cline { 3 - 4 } & & $\mathrm{T} 2$ & $\mathrm{~T} 3$ \\
\hline \multirow{3}{*}{ SBA* $^{*}$} & + & 6 & 3 \\
& \pm & 2 & 0 \\
PNA $^{* *}$ & - & 5 & 4 \\
& + & 2 & 1 \\
& \pm & 0 & 0 \\
WGA $^{* * *}$ & - & 11 & 6 \\
& + & 7 & 4 \\
& \pm & 5 & 2 \\
\hline
\end{tabular}

${ }^{*},{ }^{* *},{ }^{* * *}:$ not significant

腎細胞癌のT分類を $\mathrm{T} 2, \mathrm{~T} 3$ に分けて検討した。

SBA の蛍光染色体を+〜士を陽性, 一を陰性として 検討すると, T分類が進むにつれてその染色性は低下 する傾向が伺光た（推計学的には N.S.).

PNA，WGA に関してはSBA の如き傾向は認めら れなかった（表 6 ).

RTA は一定の傾向を示さなかった。

以上 a)〜d）までの症例別一覧表を表 7 に示す.

e) neuraminidase 処理による腎癌組織のレクチン 反応性

neuraminidase 処理切片に和けるレクチンの反応性 は，PNA が間質と弱いながら反応を示す様になった が，処理前に PNA と反応を認めなかった腫瘍細胞が 処理後に陽性になるといら所見は得られなかった。 SBA, WGA の反応性は neuraminidase 処理後子変化 は認められなかった。

\section{2. 転移性腫瘍組織}

SBA は原発巣と同様, 腫瘍細胞との反応性は低かっ
表 7 Fluorescence findings in primary renal cell carcinoma

\begin{tabular}{c|c|c|c|c}
\hline case & aRTA & SBA & PNA & WGA \\
\hline 1 & $1+$ & - & - & \pm \\
2 & $1+$ & $1+^{*}$ & - & $1+$ \\
3 & $1+$ & - & - & $1+^{*}$ \\
4 & $1+$ & $1-$ & - & $1+$ \\
5 & $1+$ & - & - & \pm \\
6 & $2+$ & $1+{ }^{*}$ & - & $1+$ \\
7 & $2+$ & \pm & - & \pm \\
8 & $1+$ & - & - & $1+^{*}$ \\
9 & $1+$ & $1+$ & - & \pm \\
10 & $1+$ & - & - & \pm \\
11 & $1+$ & - & - & - \\
12 & $1+$ & \pm & $1+{ }^{*}$ & - \\
13 & $1+$ & $1+{ }^{*}$ & - & $1+$ \\
14 & $1+$ & $1+{ }^{*}$ & - & $1+$ \\
15 & $1+$ & - & - & $1+{ }^{*}$ \\
16 & $1+$ & $1+^{*}$ & $1+{ }^{* *}$ & \pm \\
17 & $1+$ & - & - & $1+$ \\
18 & $1+$ & $1+{ }^{*}$ & - & $1+$ \\
19 & $1+$ & $1+$ & - & $1+$ \\
20 & $1+$ & - & $2+{ }^{*}$ & \pm \\
\hline
\end{tabular}

aRTA $=$ anti-renal tubular antigens

*indicate sparse fluorescence

${ }^{* *}$ positive cells in a small area

因 8 Binding of PNA to the metastatic lesion. Relatively strong fluorescence is observed at both carcinoma cells and stromal tissue.

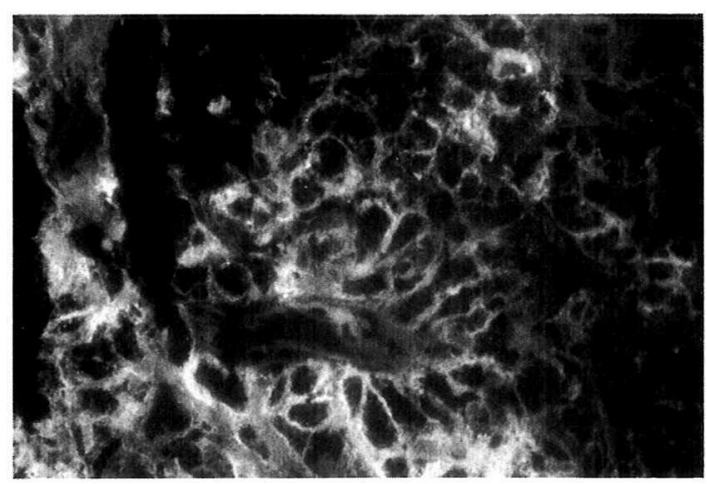

た。しかし，間質とも僅かに反応した。PNAは原発巣 に扔いては散在する少数の細胞と反応したが, 転移組 織に拈いては間質怙よび大半の細胞と反応を示した (図 8 ).WGA は原発巣と同様の反応を示し, 腫瘍細胞 扔よび間質に蛍光が認められた。

転移組織における抗 RTA 抗体との反応は, 非常に 強く反応する細胞，弱く反応する細胞，ほとんど反応 
図 9 Metastatic renal cell carcinoma stained with antibodies to renal tubular antigens. Mixed pattern of strong, weak and negative fluorescence at the carcinoma cells is seen.

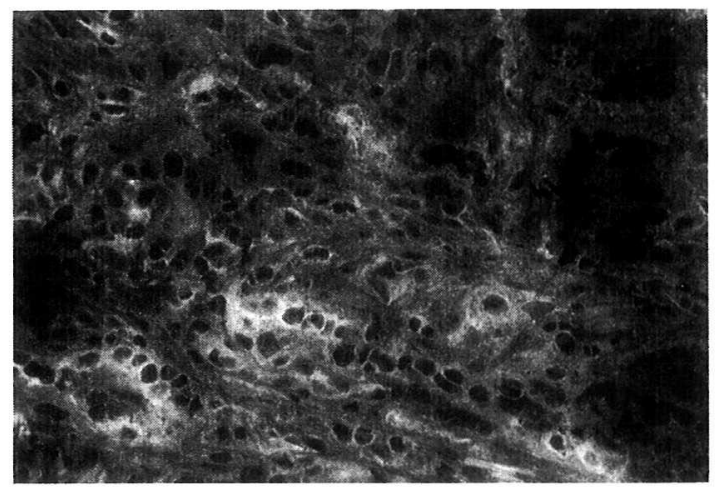

しない細胞が混在する様相を呈した（図 9 ).

3. TSU-R1ヌードマウス移植組織

ヌードマウス移植組織では, SBA, PNA は間質との み反応し, 腫瘍細胞とは反応は示さず, WGA は間質組 織に加穴, 腫瘍細胞とも弱いながら反応を示した。 RTA の場合のみ継代数が 10 代と 50 代の組織間に異っ た蛍光所見が得られた。すなわち，10代においては， RTA 溺いながら陽性であったが，50代に扔いては 陰性であった。他は10代，50代とも同様の所見を呈し た。

\section{考按}

細胞の悪性変化に伴ない, 細胞構成成分である glycocompounds (以後 GC と略す) の量, 質等に変化 が生じることは，多くの研究者の認めるところであ る(10) 15)。特に細胞膜にその大半が存在する glycolipids (以後 GL と略す)に関しては多数の報告が 認められ，これを要約すると，1）起源細胞に認められ る GL 合成の阻害㧍よびその前駆物質の増加, 2) 起源 細胞には認められないかあるいは非常に少ないGLの 増加，3）GLのある種の合成系路から別の合成系路へ の転換，4）膜における GL の編成の変化，からなる 4 つの変化様式が認められている1011115)。臨床的にも 種々の悪性腫瘍に和ける $\mathrm{ABH}$ 血液型物質の消失は, GLの合成阻害による変化の代表的な例として多数報 告されている16) 19)。また最近, モノクローナル抗体に より確認されたメラノーマや大腸癌特異抗原が GL で あったとの報告もなされている20)21)。この様に, 悪性腫 瘍に拈いて GLを含さ GCに関し検討することはその 腫場の性格および特徵を知る上で重要であると考えら
れる。そこで我々は，ある種の糖残基とそれぞれ特異 的に結合する 3 種のレクチンを用い, 腎細胞癌に拈け る GCについて蛍光染色にて検討したが，この方法は $\mathrm{GC}$ の変化を概略的に把握することができる最も簡単 な方法と思われる。 SBA は, D-N-acetylgalactosamine 扔よびD-galactose と結合し ${ }^{22)}$, 正常 部腎組織においては糸球体, 近位および遠位尿細管, 間質と反応した。しかし, 腎細胞癌における腫瘍細胞 とは, 原発腫瘍の 9 例にのみ区応し，その5ち6 例に おいては反応細胞が散在していたといら結果は，我々 の原発腫瘍全例に RTA が認められ, 近位尿細管上皮 細胞由来である可能性が強いことからすると, その大 半に括いて正常の GC の合成が阻害されている可能性 を示唆した。Holthöfer 等は腎細胞癌の $70 \%$ に扣いて SBA が腫瘍細胞と結合したと報告するとともに, 刷子 縁抗原は陽性であるがやや分化の悪い腫瘍に拈いて SBA のレセプターが欠損していたと報告してい る ${ }^{23)}$. 我々の症例では grade と SBA レセプターの有 無との関係は確認されなかったが, 手術時に所属リン パ節あるいは遠隔転移が既に存在していた 6 症例に, 手術後 1 年以内に転移が発見された 4 症例を加えた 10 例中 7 例に抏いて SBA レセプターが陰性あるいは判 定困難であり，転移が存在しない10例中 6 例にレセプ ターが陽性であったことから, sensitivityと specificity は各々70\%と60\%となり, SBAレセプター が消失するに従い，転移が生じやすくなるという可能 性が示唆された。この点に関しては今後更に検討する 必要があると考光られる。転移巣拈よびヌードマウス 移植組織においてレセプターが陰性であったことは, どちらの腫瘍細胞も grade が高く, 低分化あるいは未 分化ではあったが, 由来組織の性格をそのまま引き継 いだものと思われる。PNAはD-galactose 打よびそ の誘導体に特異的に結合し24), 正常部腎組織に括いて は遠位尿細管特よびボウマン囊との文反応し，近位尿 細管とは反応しなかったが，原発腫瘍20例中 3 例に㐨 いて少数の腫瘍細胞と反応した。これは，この3 例に おいて RTA が陽性であったことから，この細胞が遠 位尿細管上皮由来と考学るよりは，この細胞において 正常の GC の合成が阻害され, 前駆物質が増加したか, あるいは新しいGCが合成されていると考㝋た方が自 然であると思われる。ぬた，転移巣に抏いて大半の腫 瘍細胞が PNA と反応した原因としては, 由来組織の PNA レセプター陽性細胞が転移した場合と, PNAレ セプター陰性細胞が転移し, 増殖過程で変化した場合 
が考学られる.前者の場合, PNAレセプター陽性細胞 がょり転移を生じ易いのではないかという推測も成り 立つ，事実，我々の症例ではレセプタ一陽性細胞を認 めた 3 例全例に転移巣が存在したが，現時点では症例 数も少なく, 今後症例数を加光, 更に検討寸る予定で ある。一方, PNA は $\mathrm{T}$ Thomsen-Freidenreich) 抗原 に特異的なレクチンとして, 種々の悪性腫瘍において, T抗原または neuraminidase 処理により出現する cryptic T抗原の有無の検討がなされ報告されてい $3^{25) \sim 28)}$. これらの報告からすると，我々の用いた組織 はすべて組織学的悪性度が高い場合に多いとされる $\mathrm{T}$ 抗原陽性あるいは cryptic $\mathrm{T}$ 抗原陰性に分類される。 しかしながら, 他の腫瘍の場合, 起源となる正常細胞 は cryptic $\mathrm{T}$ 抗原が陽性とされており, 正常部腎組織 に打いて，近位尿細管上皮細胞が neuraminidase 処理 後も PNA と反応しなかったことからすると，腎細胞 癌に打ける PNA との反応性の検討は, 他腫瘍におけ る T抗原の検討とは多少, 意味が異なると思われる。 WGA は D-N-acetylglucosamine およびシアル酸と 結合し ${ }^{29)}$ ，正常部腎組織に拈いてはSBA とほぼ同じ 部位に反応した, neuraminidase 処理切片に括いては, 糸球体の蛍光のみが減弱し，他には変化が認められな かったことから, 糸球体に括けるWGAレセプターは シアル酸であり，他は D-N-acetylglucosamine と考克 られた。また，WGA は腫瘍細胞とも55\%に反応した が，その反応性と悪性度あるいは転移との関連性は認 められなかった。

一般的に腎細胞癌はその大部分が近位尿細管上皮細 胞由来であると考兄られている。その根拠の一つとし $\tau$, 電子顕微鏡的に, 腎細胞癌細胞之近位尿細管上皮 細胞の間に刷子縁様の microvilli の存在，細胞膜の嵌 入，多数の蛇行したミトコンドリアの存在などの類似 点が認められることがあげられている30) 321. 一方 Wallace 等は蛍光抗体法を用い, 正常腎において近位 尿細管上皮細胞に存在する刷子縁抗原が腎細胞癌にも 存在することをを証明することにより，その近位尿細 管上皮由来説を支持している33). しかしながら，Wallace 等は同時に，未分化な腫瘍に执いて刷子縁抗原が 認められなかったと報告し，未分化な腎細胞では刷子 縁抗原が消失する可能性を示唆した。我々は成清等の 方法 ${ }^{779)}$ に準じ得た可溶化したRTAにより抗 RTA を 作製し，直接蛍光抗体法を用いて腎細胞癌について検 討したところ，原発腫瘍の全例に RTA の存在を認め た。これは，我々検討した腫瘍が近位尿細管由来であ
る可能性を強く示唆するものである，また，我々の症 例は全例 grade 1あるいは grade 2の腫瘍であり， gradeの高い未分化な組織がなかったために全例に RTA が認めらるたものと思われるが，ヌードマウス 移植組織に扣いて継代数 10 代の時点では RTA が存在 し，50代に扔けるより未分化な組織では RTA が認め られなかったことは，やはり未分化腫瘍に扣ける RTA の消失の可能性を示しているものと考兄られ た.しかし grade 2 から grade 3 と原発腫瘍よりも grade の高い細胞が大半を占めた転移組織に掞いて抗 RTA 抗体と強く反応した細胞と反応を示さなかった 細胞が混在したことは, 腫瘍細胞の増殖過程において しばしば認められる性質の変化はすべてが同一方向に 向うとは限らないことを推測させるものと思われる。

\section{結 語}

ヒト腎細胞癌 20 症例の原発性腫瘍組織怙よびその転 移腫瘍組織, ヌードマウス移植腎細胞癌由来組織にお いて，細胞表面桾鎖蛋白質と反応する 3 種類のレクチ ン (soybean agglutinin; SBA, peanut agglutinin; PNA, wheat germ agglutinin ; WGA) および抗近位 尿細管細胞上皮抗体を用いて営光抗体法招よび蛍光染 色法を施行した。その結果以下の成績をえた。

I） 3 種類のレクチンの腎癌細胞における検討結果

1）陽性頻度は SBA 45\%, PNA 15\%, WGA 55\%で あった。

2）細胞型との関係では必ずしも一定の傾向が伺学 なかった。

3）分化度との関係では, 分化度が進むと反応性が低 下した（SBA）。

4） T分類この関係では SBA で $\mathrm{T}_{3}$ になるとその反 応性が低下する傾向が伺学た（推計学的には N.S.）。

5) cryptic T 抗原の存在は必ずしも明らかにする ことが出来なかった。

II) RTA の存在

すべての腎癌組織でその存在が認められたが， ヌー ドマウス，継代50代ではその抗原性が消失した。

以上の成績より，これらレクチン反応性，および尿 細胞抗原の存在をさぐる方法は腎細胞癌個々の性質, 特徵ひいては悪性度を概略的に把握することが出来る 有効な方法であると考えられた。

稿を終るにあたり染色体分析に於て多大なる御指導, 御 協力を賜った本学基礎医学系人類遺伝学近藤郁子先生に深 謝いたします。

本論文の一部は第73回日本泌尿器科学会総会（徳島 
1984)，第43回日本癌学会総会(福岡1984)，第27回日本腎臓 学会総会（東京1984）に拈いて発表した。

なお本研究は,

1）昭和58年度筑波大学学内プロジェクト一般研究助成

2) 昭和58年度財団法人ガン集学的治療研究財団助成

により行われたものである。記して感謝の意を表します。

\section{文献}

1) Robson, C.J., Churchill, B.M. and Anderson, W.: The results of radical nephrectomy for renal cell carcinoma. J. Urol., 101, 297-301, 1969.

2) Skinner, D.G., Colvin, R.B., Vermillion, R.C. and Leabetter, W.F.: Diagnosis and management of renal cell carcinoma. A clinical and pathological study of 309 cases. Cancer, 28, 1165-1177, 1971.

3) McNichols, D.W., Segura, J.W. and DeWeerd, J. H.: Renal cell carcinoma : Long-term survival and late recurrence. J. Urol., 126, 17-23, 1981.

4）里見佳昭, 高井修道, 近藤猪一郎, 岩崎孝史, 吉邑 貞夫, 福島修司, 古烟哲彦, 石塚栄一: 灯細胞癌の stage 及び grade と予後. 日泌尿会誌, 72, 278-287, 1981.

5）船越育雄：ガン細胞膜のムチン型糖タンパク質. 生化学, 55(7), 461-477, 1983.

6）过勉, 恒久生子, 大沢利昭：生体膜と薬物の相 互作用. 第 5 回同シンポジゥム講演要旨集, p. 36-39, 1982.

7）成清卓二, 北村 潔, 宮川侑三, 柴田整一：可溶性 ヒト尿細管上皮抗原の pronase 消化による抽出及 び Membranous glomerulonephritis $の$ immune deposits 中における存在について。日腎誌，15, 217-222, 1973.

8) 日本泌尿器科学会, 日本病理学会, 日本放射線学 会：腎癌取り扱い規約. 第 1 版, 金原出版, 東京, 1983.

9) Naruse, T., Kitamura, K., Miyakawa, Y. and Shibata, S.: Deposition of renal tubular epithelial antigen along the glomerular capillary walls of patients with membranous glomerulonephritis. J. Immunol., 110, 1163-1166, 1973.

10) Gahmberg, C.G. and Hakmori, S.: Chemical characterization of surface-labeled glycosphingolipids and a specific ceramide tetrasccharide for transformats. J. Biol Chem., 250, 2438-2446, 1975.

11) Hakomori, S.: Stracctures and organization of cell surface glycolipids dependency on cell growth and malignant transformation. Biochim. Biophys. Acta, 417, 55-89, 1975.

12) Ogata, S., Murmatsu, T. and Kobata, A.: New structural characteristic of the large glycope- ptides from transformed cells. Nature, 259, 580-582, 1976.

13) Warren, L., Buck, C.A. and Tuszynski, G.P.: Glycopeptide changes and malignant transformation. A possible role for carbohydrate in malignant behavior. Biochim. Biophys. Acta, 516, 97-127, 1978.

14) Tuszynski, G.P., Baker, S.R., Fuhrer, J.P., Buck, C.A. and Warren, L.: Glycopeptides derived from individual membrane glycoproteins from control and rous sarcoma virus-transformed hamster fibroblasts. J. Biol. CHem., 253, 6092-6099, 1978.

15) Hakomori, S.: Tumor-associated glycolipid markers in experimental and human cancer. GANN Monographyon Cancer Research 29: 113-127, Japan Scientific Societties Press, Tokyo, and Plenum Press, New York and London, 1983.

16) Davidsohn, I., Kovarik, S. and Lee, C.L.: A,B, and $\mathrm{O}$ substances in gastrointestinal carcinoma. Arch. Oathol., 81, 381-390, 1966.

17) Davidsohn, I., Kovaric, S. and Ni, L.Y.: Isoantigens $\mathrm{A}, \mathrm{B}$, and $\mathrm{H}$ in benign and malignant lesions of the cervix. Arch. Pathol., 87, 306-314, 1969.

18) Davidsohn, I.: Early immunologic diagnosis andprognosis of carcinoma. Am. J. Clin. Pathol., 57, 715-730, 1972.

19) Emmott, R.C., Javadpour, N., Bergman, S.M. and Soares, T.: Correlation of the cell surface antigens with stage and grade in cancer of the bladder. J. Urol., 121, 37-39, 1979.

20) Magnani, J.L., Brockhaus, M., Smith, D.F., Ginsburg, V., Blaszczyk, M., Mitchell, K., Steplewski, Z. and Koprowski, H.: A monosialoganglioside is a monoclonal antibody-defined antigen of coloncarcinoma. Science, 212, 53-54, 1981.

21) Pukel, C.S., Lloyd, K.O., Travassos, L.R., Dippold, W.G., Oettgen, H.F. and Old, L.J.: GD3, a prominent ganglioside of human melanoma. J. Exp. Med., 155, 1133-1147, 1982.

22) Lis, H., Sela, B.A., Sacks, L. and Sharon, N.: Specific inhibition by $\mathrm{N}$-acetyl-O-galactosamine of the interaction between soybean allgutinin and animal cell surfaces. Biochim. Biophys. Acta, 211, 582-585, 1970.

23) Holthofer, H., Miettinen, A., Passivuo, R., Lehto, V.P., Linder, E., Alfthan, O. and Virtanen, I.: celklular origine and differentiati:n of renal carcinomas. A fluorescence micros- 
copic study witn kidney specific antibodies, antiintermediate filament antibodies and lectins. Lab. Invest, 49, 317-326, 1983.

24) Lotan, R., Skutelsky, E., Danon, D. and Sharon, N.: The purification, composition and specificity of the anti- $\mathrm{T}$ lectins from peanut (Arachis hypogaea). J. Bio. Chem., 250, 8518-8523, 1975.

25) Springer, G.F., Desai, P.R., Yang, H.J. and Murthy, M.S.: Carcinoma associated blood group MN precursor antigens against which all humans possess antibodies. Clin. Immunol. Immunopathol., 7, 426-441, 1977.

26) Springer, G.F., Desai, P.R., Murthy, M.S., Yang, H.J. and Scanlon, E.F.: Preccursos of the blood group MN antigens as human carcinomaassociated antigens. Transfusion, 19, 233-249, 1979.

27) Coon, J.S., Weinstein, R.S. and Summers, J.L. : Blood group precursor $\mathrm{T}$-antigen expression in human urinary bladder carcinoma. Am. J. Clin. Pathol., 77, 692-699, 1982.

28) Ghazizadeh, M., Kagawa, S., Izumi, K. and Kurokawa, K.: Immunohistochemical local- ization of T-antigen-like substance in benign hyperplasia and adenocarcinoma of theprostate. J. Urol., 132, 1127-1130, 1984.

29) Bhavanandan, V.P. and katlic, A.W.: The interaction of wheat germ agglutinin with sialoglycoproteins. J. Biol. Chem., 254, 4000-4008, 1979.

30) Oberling, C., Riviere, M. an Haguenan, F.: Ultrastructure of the clear cells in renal carcinomas and its importance for the demonstration of their renal origine. Nature, 186, 402-403, 1960.

31) Seljelid, R. and Ericsson, J.L.E.: An electron microscopic study of mitochondria in renal cell carcinoma. J. Microscopie, 4, 759-770, 1965.

32) Seljelid, R. and Ericsson, J.L.E.: Electron microscopic observations on specialization of the cell surfact in renal clear cell carcinoma. Lab. Invest., 14, 435-447, 1965.

33) Wallace, A.C. and Nairn, ;R.C.: Renal tubular antigens in kidney tumors. Cancer, 29, 977-981, 1972.

（1985年11月11日受付，特別掲載） 